\title{
JURNAL
}

\section{Aplikasi Stockwell Transforms dan K-Nearest Neighbor untuk Klasifikasi Sinyal Elektrokardiogram}

\author{
Dyah Ayu Pratiwi ${ }^{1)}$, Achmad Rizal ${ }^{2)}$, Rita Magdalena ${ }^{3)}$ \\ ${ }^{1,2,3)}$ Fakultas Teknik Elektro, Telkom University \\ J1. Telekomunikasi no 1, Ters. Buah Batu, Kab. Bandung \\ Email : achmadrizal@telkomuniversity.ac.id
}

$\begin{array}{ccc}\text { Riwayat artikel: } & \\ \text { Recieved: } 17-03-2020 & \text { Accepted: 22-07-2020 }\end{array}$

\section{Abstract}

An electrocardiogram signal is a bio-electrical signal that results from the electrical activity of the heart. Information on heart health conditions can be inferred by analyzing its shape, rhythm, duration, and orientation. Various methods have been developed to analyze or classify ECG signals automatically. Some of them use the transformation method to convert signals from the time domain to another signal domain. In this study, the Stockwell transform (S-transform) was used to convert signals from the time domain to the time-frequency domain. Minimum and maximum values of the time series of Stransforms were used as K-NN inputs as classifiers. The classification accuracy of $S$ transform was compared with the accuracy of the short-time Fourier transform (STFT), which is an equivalent transformation. The test results showed that S-transform produced higher accuracy compared to FFT on the six classes of ECG signal data tested.

Keywords: electrocardiogram, short-time Fourier transform, Stockwell transform, K-NN

\begin{abstract}
Abstrak
Sinyal elektrokardiogram (EKG) adalah sinyal bio-elektrik yang dihasilkan dari aktifitas kelistrikan jantung. Informasi dari kondisi kesehatan jantung bisa diketahui dengan menganalisis bentuk, irama, durasi, maupun orientasi sinyal EKG. Berbagai metode dikembangkan untuk melakukan analisis atau mengklasifikasi sinyal EKG secara otomatis. Beberapa diantaranya menggunakan metode transformasi untuk mengubah sinyal dari domain waktu ke domain sinyal yang lain. Pada penelitian ini digunakan Stockwell transform (S-transform) untuk mengubah sinyal dari domain waktu ke domain waktu-frekuensi. Nilai minimum dan maksimum pada deretan waktu dari S-transform digunakan sebagai masukan K-NN sebagai classifer. Akurasi klasifikasi dari penggunaan S-transform dibandingkan dengan akurasi penggunaan short-time Fourier transform (STFT) yang merupakan transformasi yang setara. Hasil pengujian menunjukkan akurasi $S$-transform lebih tinggi dibandingkan dengan FFT pada enam kelas data sinyal EKG yang diuji.
\end{abstract}

Kata kunci: elektrokardiogram, short-time Fourier transform, Stockwell transform, K$\mathrm{NN}$ 


\section{Pendahuluan}

Elektrokardiogram (EKG) adalah sinyal sinyal elektrik yang dihasilkan dari kontraksi otot pada jantung yang berakibat pemompaan darah ke seluruh tubuh [1]. Sinyal EKG memiliki suatu informasi yang merepresentasikan kondisi jantung. Biasanya dinilai berdasarkan bentuk, irama, orientasi, dan durasi [2]. Teknik penilaian sinyal EKG paling dasar yaitu menilai secara visual dari kertas rekaman EKG yang dilakukan oleh dokter. Penilaian seperti ini membutuhkan keahlian dan pengalaman dari dokter. Mengingat keterbatasan jumlah dokter spesialis jantung, maka dirasa perlu dibangun sistem untuk menganalisis sinyal EKG untk membantu dokter memberikan analisis awal sinyal EKG.

Berbagai teknik dikembangkan untuk menghasilkan metode yang dapat mengklasifikasi sinyal EKG menggunakan komputer. Selain metode pada domain waktu [3], berbagai metode tranformasi sinyal digunakan untuk menganalisis sinyal seperti transformasi Fourier [4], tranformasi wavelet [5][6], maupun transformasi domain waktu-frekuensi seperti short-time Fourier transform (STFT) [7]. STFT merupakan metode yang sederhana dalam untuk melakukan transformasi dari domain waktu ke domain waktu-frekuensi. Pada STFT, dilakukan segmentasi sinyal kemudian dilakukan transformasi Fourier pada segmen sinyal tersebut. Hal ini menyebabkan resolusi di domain waktu dan frekuensi sangat tergantung pada panjang segmen sinyal yang dilakukan FFT. Segmen sinyal yang panjang akan menurunkan resolusi ada domain waktu dan menaikkan resolusi pada domain frekuensi, demikian sebaliknya [8]. Xia dkk menggunakan STFT dan deep convolutional neural network untuk mendeteksi atrial fibrillation [7]. Sementara itu metode yang hampir sama digunakan oleh Huang dkk. Untuk mendeteksi arrhythmia pada sinyal EKG [9]. Kedua penelitian tersebut menggunakan masukan berupa matrik 2D dari spektrogram hasil STFT sebagai masukan. Hal ini membutuhkan teknik klasifikasi yang canggih yaitu deep learning. Selain untuk klasifikasi sinyal EKG, STFT juga bisa digunakan dalam pengolahan komponen sinyal dalam sinyal EKG [10]. Pada metode ini, STFT digunakan untuk memperhalus sinyal atau mengekstraksi komponen sinyal EKG.

Dari uraian di atas, kelemahan dari STFT adalah trade-off antara panjang segmen dan resolusi dari spektrogram. Kelemahan ini diatasi dengan adanya Stockwell transform atau S-transform yang menggunakan Gaussian window pada segmentasi sinyal. Pada penelitian ini diusulkan metode klasifikasi sinyal EKG menggunakan Stransform. Resolusi tinggi dari S-transform diharapkan mampu menghasilkan akurasi yang lebih tinggi dari pada STFT. Untuk itu pada penelitian ini dibandingkan performansi FFT dan S-transform menggunakan K-NN sebagai classifier. Pada penelitian ini dipilih metode K-NN yang sederhana sebagai classifier untuk menunjukkan bahwa metode yang digunakan tidak membutuhkan komputasi yang tinggi. Hasil yang didapat diharapkan dapat menjadi alternatif metode pengolahan sinyal EKG menggunakan transformasi pada domain waktu-frekuensi. 


\section{Kajian Pustaka}

Elektrokardiogram (EKG) adalah sinyal listrik yang terjadi akibat aktifitas jantung yang menggambarkan kondisi jantung [1]. Sinyal EKG dapat menggambarkan kondisi kesehatan jantung seseorang melalui irama, durasi, bentuk, dan orientasinya. Sinyal EKG normal terdiri dari sinyal P, Q, R, S, dan T yang mewakili depolarisari atrium, depolarisasi ventrikel, dan repolarisasi ventrikel [11]. Perubahan bentuk dan orientasi dari sinyal EKG normal mengindikasikan kelainan yang terjadi pada jantung. Beberapa kelainan jantung diantaranya: atrial fibrilation (AF), ventricular tachicardia (VT), ventricular fibrilation (VF), prematur ventricular contraction (PVC), paced rhytms (PR).

Pada AF terjadi kontraksi otot jantung tidak beraturan sehingga proses pemompaan darah menjadi tidak efisien [12]. AF terjadi karena kelainan atau gangguan impuls listrik pada jantung. Pada VT, irama jantung menjadi sangat cepat di ventrikel. Sementara itu pada VF, irama jantung terjadi sangat cepat di ventrikel namun menpunyai kecepatan dan ritme yang tidak teratur dan bentuk yang berbeda. PVC adalah denyut jantung terjadi sebelum waktunya atau prematur yang berasal dari ventrikel [11]. PR merupakan bentuk sinyal EKG dengan QRS yang terjadi berulangulang tetapi tidak muncul gelombang $\mathrm{P}$.

Short-time Fourier Transform (STFT) atau spectrogram merupakan metode transformasi sinyal dari domain waktu ke domain domain waktu-frekuensi. Pada algoritma ini, sinyal akan disegmen pada selang waktu tertentu tertentu. Sinyal hasil segmentasi ditransformasi menggunakan FFT ke domain frekuensi. Persamaan (1) menampilkan ekspresi matematis dari STFT.

$$
\operatorname{STFT}(\tau, f)=\int_{-\sim}^{\sim} h(t) g(t-\tau) e^{-j 2 \pi f t} d t
$$

dimana $\tau$ menunjukkan waktu lokasi spektral dan $f$ merupakan frekuensi, sedangkan $\mathrm{g}(\mathrm{t})$ menunjukkan fungsi window yang digunakan dalam STFT. Ilustrasi STFT ditampilkan pada Gambar 1. STFT mencuplik sinyal pada window yang ditentukan dan melakukan FFT pada tiap cuplikan sinyal. Selanjunya hasil proses ini ditata menjadi representasi sinyal dalam domain waktu-frekuensi.
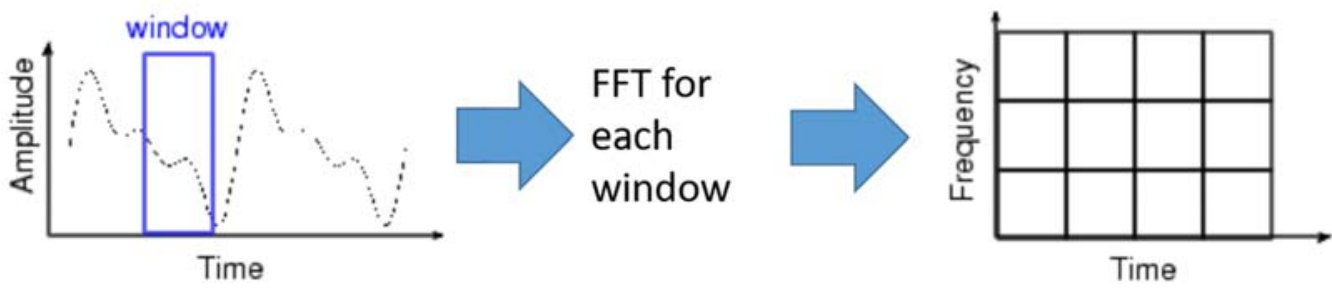

Gambar 1 Short Time Fourier Transforms

Transformasi Stockwell (S-transform) merupakan metode transformasi sinyal dari domain waktu ke domain waktu-frekuensi [8]. S-transform mampu melakukan 
analisis sinyal yang berubah terhadap waktu secara multiresolusi. Perbedaan $S$ transform dengan STFT adalah penggunaan Gaussian window yang mempunyai kemampuan adaptasi pada lebar dan amplitudo terhadap variasi frekuensi. Secara matematis Gaussian window ditulis seperti Persamaan (2).

$$
g(t)=\frac{|f|}{\sqrt{2 \pi}} e^{\frac{-t^{2} f^{2}}{2}}
$$

Karena S-transform berasal dari Persamaan (1) dengan mengganti fungsi window $g(t)$ dengan Persamaan (2) maka S-transform dapat didefinisikan seperti Persamaan (3).

$$
S(\tau, f)=\operatorname{STFT}(\tau, f)=\int_{-\sim}^{\sim} h(t) \frac{|f|}{\sqrt{2 \pi}} e^{\frac{(\tau-t)^{2} f^{2}}{2}} e^{-j 2 \pi f t} d t
$$

dimana $f$ adalah variabel frekuensi, $t$ adalah variabel waktu dan $\tau$ adalah pergeseran waktu. Lebar fungsi Gaussian window proporsional dengan kebalikan dari frekuensi. Spektrum Stockwells $(\tau, f)$ menyatakan bagaimana komponen frekuensi pada sinyal bervariasi dari waktu ke waktu. S-transforms mengatasi kelemahan STFT yang mengakibatkan diskontinuitas dalam representasi waktu-frekuensi dan dan resolusi yang tergantung dari panjang cuplikan sinyal [8]. S-transform merupakan suatu kasus khusus pada STFT yang berbasis pada Gaussian window. Penyajian umum S-transforms pada penerapannya memiliki ketergantungan pada window yang digunakan. Untuk aplikasi yang berbeda, dapat dipilih window yang tepat dan parameter tertentu untuk memperoleh resolusi yang lebih baik pada bagian yang ditekankan.

\section{Metode Penelitian}

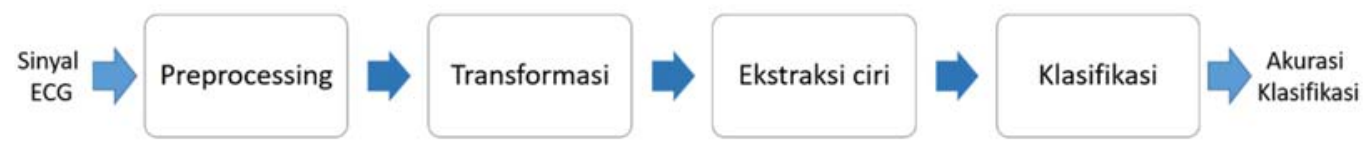

Gambar 2 Metode yang diusulkan

Metode yang diusulkan pada penelitian ini seperti ditampilkan pada Gambar 2. Masukan dari sistem ini adalah sinyal EKG dengan lima jenis kelainan dan EKG normal sebagai pembanding. Selanjutnya pada sinyal EKG dilakukan preprocessing untuk menormalisasi amplitudo sinyal. Pada tahap berikutnya dilakukan transformasi untuk merubah sinyal dari domain waktu ke domain waktu-frekuensi. Pada penelitian ini digunakan transformasi Stockwell dan STFT sebagai pembanding. Proses ekstraksi ciri dilakukan untuk mendapatkan karakteristik dari sinyal dalam domain waktu-frekuensi. Performansi ekstraksi ciri dilakukan dengan menghitung akurasi hasil klasifikasi menggunakan K-NN. Detail dari proses di atas dijelaskan pada subbagian berikut ini.

Data masukan pada sistem ini berupa sinyal EKG berformat .mat dengan panjang rekaman data kurang lebih 4 detik. Sinyal EKG diambil dari website physionet.org yang dipotong sehingga menampilkan paling tidak 3 - 6 sinyal QRS [13]. Frekuensi pencuplikan yang digunakan pada sistem yang dirancang sebesar $1000 \mathrm{~Hz}$. Data sinyal 
EKG terdiri dari 60 data latih dan 60 data uji dengan rincian AF, NSR, VT, PR, VF, dan PVC masing-masing 10 data latih dan 10 data uji.

Pada tiap data dilakukan proses normalisasi untuk menyeragamkan rentang amplitudo data menggunakan Persamaan (4).

$$
y(n)=\frac{x(n)}{\max |x|}
$$

dengan $x(n)$ adalah sinyal masukan dan $y(n)$ adalah sinyal hasil normalisasi. Menggunakan proses di atas maka sinyal EKG akan mempunya rentang -1 sampai +1 .

Tahap selanjutnya dilakukan S-transform untuk mengubah sinyal dari domain waktu ke domain waktu-frekuensi. Pada penelitian ini digunakan Gaussian window dengan lebar 10 sampel non-overlap dan NFFT 1000 titik. Dengan demikian nantinya akan didapat matrik berukuran 1000 x 400 untuk representasi tiap sinyal. Selanjutnya akan diambil nilai minimum dan nilai maksimum dari tiap kolom pada matrik hasil $S$ transform. Proses ini akan menghasilkan 400 nilai maksimum dan 400 nilai minimum yang dijadikan ciri dari tiap sinyal. Ciri nilai minimum ini adalah nilai minimum yang diambil dari tiap kolom dari matrik1000 x 400 hasil S-transform. Sedangkan ciri nilai maksimum adalah nilai maksimum diambil dari tiap kolom dari matrik1000 x 400 hasil S-transform. Nilai-nilai ini menggambarkan fluktuasi frekuensi pada tiap rentang waktu. Jumlah ciri ini lebih sedikit dibandingkan dengan sinyal asli yang terdiri 4000 sampel sinyal. Pada tahap selanjutnya lebar window diubah menjadi 5, 10, dan 20 untuk melihat pengaruh lebar window terhadap akurasi.

Untuk STFT, dilakukan hal sama dengar beberapa perbedaan. Window yang digunakan adalah rectangular window dengan lebar 10 sampel. Kemudian NFFT 1000 titik digunakan untuk mengubah sinyal dari domain waktu ke domain frekuensi. Pada matrik hasil transformasi ini diambil nilai maksimum dan minimum seperti halnya pada S-transform.

K-nearest neighbor (K-NN) merupakan metode klasifikasi yang menggunakan jarak dalam menentukan hasil klasifikasi berdasarkan kelas data latih yang terbanyak yang mempunyai jarak terdekat dengan data uji [14]. Secara sederhana K-NN dapat dijelaskan seperti dalam Gambar 3.

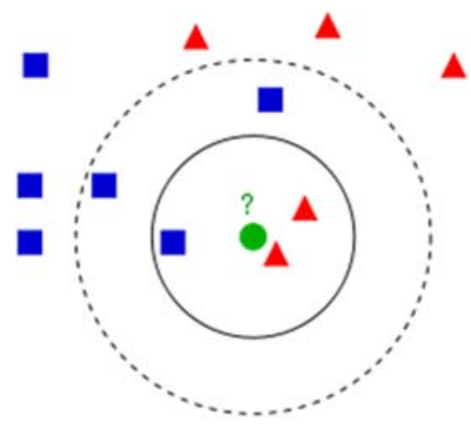

Gambar 3 Illustrasi K-NN 
Pada saat ditentukan nilai $\mathrm{K}=3$, maka dicari tiga data latih terdekat dengan data uji. Pada Gambar 3, maka data uji akan dikenali sebagai bagian dari segitiga merah karena terdapat dua data latih yang lebih dekat dengan data uji (lingkaran hijau). Jika ditentukan $\mathrm{K}=5$, maka data uji akan dikenali sebagai bagian dari segiempat biru. Jarak antar data pada K-NN dihitung beberapa metode sebagai berikut:

- Euclidean Distance

$$
D_{l_{2}}\left(\mathrm{x}_{2}-\mathrm{x}_{1}\right)=\left\|\mathrm{x}_{2}-\mathrm{x}_{1}\right\|=\sqrt{\sum_{j=1}^{p}\left(x_{2 j}-x_{1 j}\right)^{2}}
$$

- Cityblock Distance

$$
D_{l_{2}}\left(\mathrm{x}_{2}-\mathrm{x}_{1}\right)=\left\|\mathrm{x}_{2}-\mathrm{x}_{1}\right\|=\sum_{j=1}^{p}\left|x_{2 j}-x_{1 j}\right|
$$

- Cosine similarity

|. $\quad$ : Nilai absolute

dimana $p$ adalah dimensi data dan $|$.$| adalah nilai absolut.$

\section{Hasil dan Pembahasan}

Gambar 4 menampilkan sinyal EKG yang digunakan dalam penelitian ini. Karena frekuensi sampling $1000 \mathrm{~Hz}$ dan lama rekaman 4 detik maka akan dihasilkan panjang sampel 4000. Tiap data terdiri dari 3-5 atau lebih puncak QRS yang mewakili jumlah detak jantung. Pada kelainan tertentu tidak dapat diidentifikasi puncak gelombang QRSnya. Jumlah ini berbeda-beda karena perbedaan heart-rate, jenis kelainan, dan arah orientasi sinyal EKG.

Hasil STFT dan S-transform untuk sinyal EKG-AF pada Gambar 4 ditampilkan pada Gambar 5. Perbedaan yang terlihat jelas pada hasil kedua transformasi adalah pada detail resolusi. Pada STFT, apabila window yang digunakan panjang, maka resolusi pada domain waktu akan menurun tetapi resolusi pada domain frekuensi meningkat. Hal ini tidak terjadi pada S-transform dimana penggunaan Gaussian window menjamin resolusi yang merata setiap pita frekuensi. Pada Gambar 5(a) terlihat diskontinyuitas pada representasi waktu dan frekuensinya sementara pada Gambar 5(b) hasil Stransform cenderung lebih halus dan tidak terlihat transisi antar segmen sinyal pada domain waktu.

Hasil ekstraksi ciri berupa nilai maksimum dan nilai minimum dari sinyal EKGAF dari dua jenis tranformasi yang dilakukan seperti pada Gambar 6. Nilai maksimum dan minimum dari domain waktu ini dimaksudkan untuk menangkap selubung dari hasil transformasi. Pada penelitian lainnya penggunaan nilai maksimum pada STFT suara paru menghasilkan akurasi yang cukup tinggi [15]. Maka pada penelitian ini, selain nilai maksimum, juga dieksplorasi nilai minimum dari STFT maupun dari S-transform. Secara umum ciri keduanya relatif sama dengan puncak yang menunjukkan QRS dari 
sinyal EKG. Perbedaan terdapat pada detail dimana pada STFT lebih banyak fluktuasi yang biasanya terjadi pada transisi tiap segmen window.

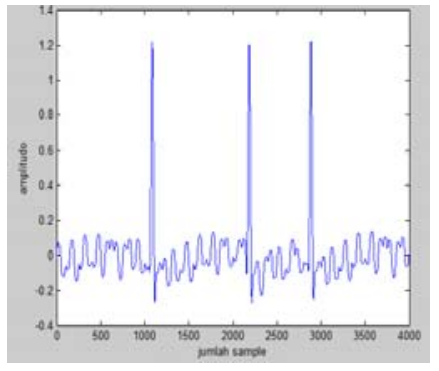

(a)

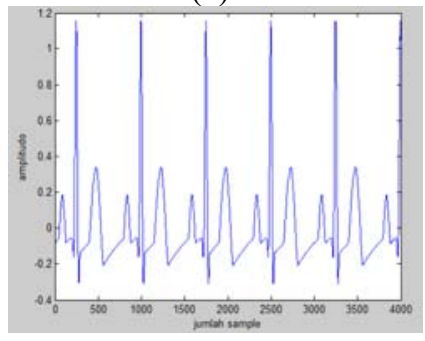

(d)

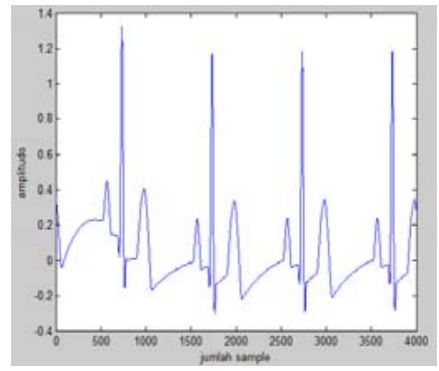

(b)

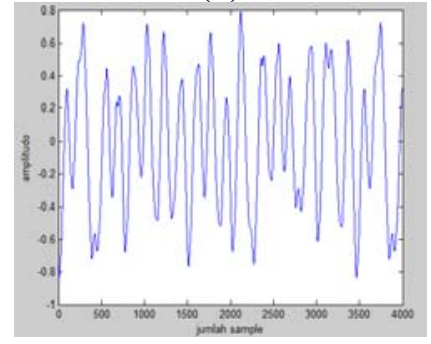

(e)

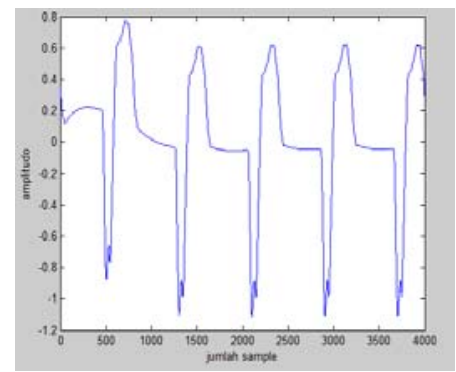

(c)

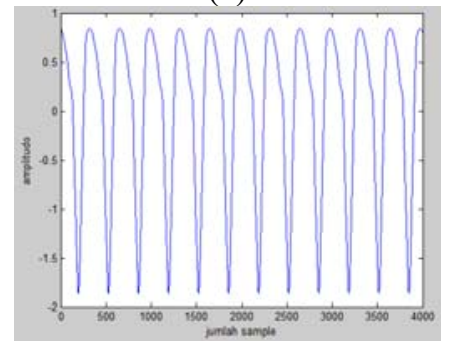

(f)

Gambar 4 (a) Sinyal EKG-AF, (b) Sinyal EKG-NSR, (c) Sinyal EKG-PR, (d) Sinyal EKGPVC, (e) Sinyal EKG-VF, (f) Sinyal EKG- VT

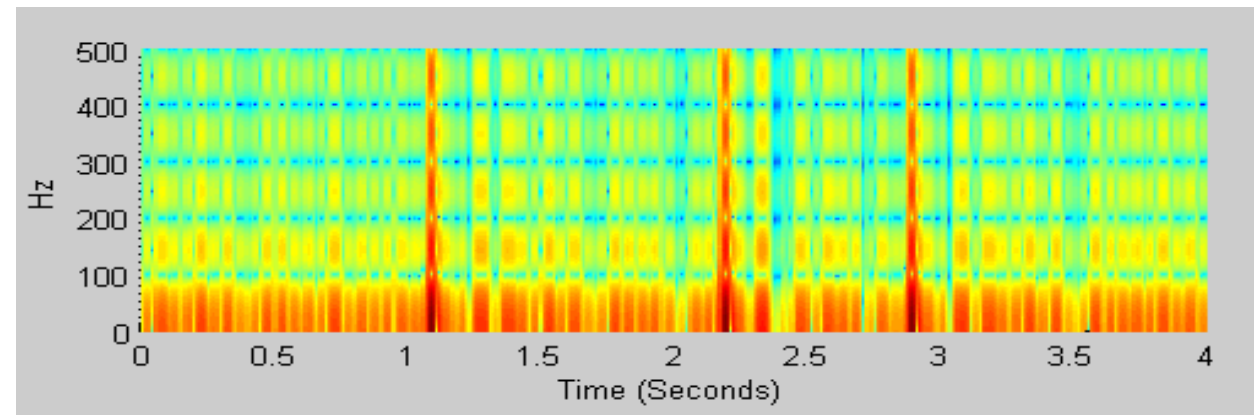

(a)

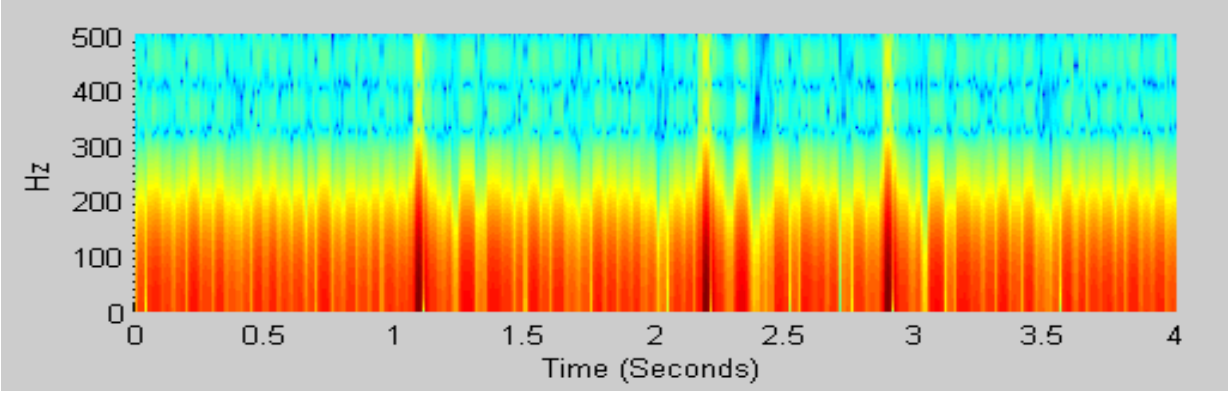

(b)

Gambar 5 (a) Hasil STFT dari sinyal EKG- AF (b) Hasil S-transform dari sinyal EKG-AF dengan lebar segmen 10 sampel dan $\alpha=2,5$ 


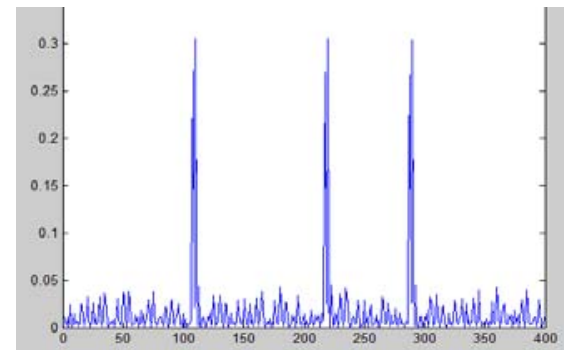

(a)

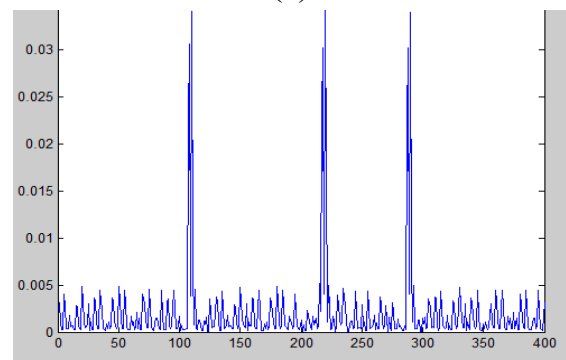

(c)

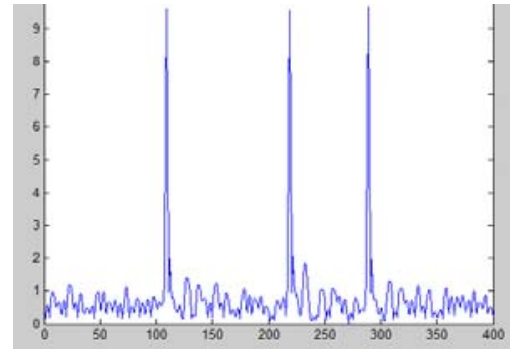

(b)

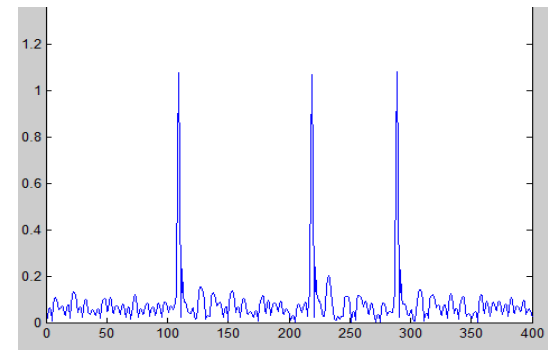

(d)

Gambar 6 (a) Ciri minimum hasil STFT pada EKG-AF (b) Ciri maksimum hasil STFT pada EKG-AF (c) Ciri minimum hasil S-transform pada EKG-AF (d) Ciri maksimum hasil $S$ transform pada EKG-AF

Tabel 1 dan Tabel 2 menampilkan akurasi klasifikasi menggunakan berbagai nilai $\mathrm{K}$, pengukuran jarak, dan ciri. Akurasi tertinggi 76,67 persen dihasilkan oleh ciri minimum dengan $\mathrm{K}=3$ dan jarak cityblock. Akurasi ini tidak dipengaruhi oleh lebar window. Hasil ini lebih baik dibandingkan dengan akurasi tertinggi pada STFT sebesar 70 persen menggunakan $\mathrm{K}=3$ dan $\mathrm{K}=5$ dengan jarak cityblok seperti ditampilkan pada Tabel 3. Jarak cityblock menghasilkan akurasi yang lebih tinggi karena kemampuannya menghasilkan jarak yang lebih jauh dibandingkan dengan jarak Euclidean maupun cosine. Dengan jarak yang lebih jauh maka keterpisahan antar data menjadi lebih besar.

STFT dan S-transform dipengaruhi oleh berapa hal seperti pemotongan sinyal, panjang window/segmen sinyal yang akan di FFT, dan resolusi FFT. Pemilihan ciri yang dihitung dari hasil transformasi juga berperan pada akurasi. Ciri lain yang digunakan dalam penelitian sebelumnya seperti parameter statistik [16], sample entropy [17], variogram [18] dan lain-lain. Karena STFT atau S-transform berupa matrik dua dimensi maka analisis citra bisa dilakukan untuk mengolah lebih lanjut.

Sekalipun hasil akurasi dari S-tranform tidak terlalu tinggi, S-transform memberikan peluang untuk pengembangan penelitian lebih lanjut. Pemotongan data sinyal EKG yang memperhatikan lokasi dari gelombang QRS akan memberikan data yang lebih seragam. Selain itu ekplorasi terhadap parameter pada window Gaussian yang dipakai juga menarik untuk dilakukan. Pemilihan metode berbagai ekstraksi ciri juga akan menantang dilakukan pada selanjutnya. Metode yang diusulkan juga diharapkan bisa digunakan untuk kasus sinyal biomedis yang lain seperti suara jantung, suara paru, sinyal EEG, sinyal EMG, dan lain-lain. 
Tabel 1 Akurasi pada Berbagai Jarak, Nilai K, dan Ciri yang Digunakan pada S-transform dengan lebar window 5

\begin{tabular}{cccc}
\hline \multirow{2}{*}{ K } & Jarak & \multicolumn{2}{c}{ Akurasi } \\
\cline { 3 - 4 } & & ciri minimum & ciri maksimum \\
\hline 3 & Cosine & $43,33 \%$ & $35 \%$ \\
& Euclidean & $46,67 \%$ & $56,67 \%$ \\
& Cityblock & $76,67 \%$ & $51,67 \%$ \\
\multirow{2}{*}{5} & Cosine & $26,67 \%$ & $23,33 \%$ \\
& Euclidean & $45 \%$ & $41,67 \%$ \\
& Cityblock & $73,33 \%$ & $45 \%$ \\
7 & Cosine & $26,67 \%$ & $25 \%$ \\
& Euclidean & $40 \%$ & $43,33 \%$ \\
& Cityblock & $65 \%$ & $36,67 \%$ \\
\hline
\end{tabular}

Tabel 2 Akurasi pada Berbagai Jarak, Nilai K, dan Ciri yang Digunakan pada S-transform dengan lebar window 10

\begin{tabular}{cccc}
\hline \multirow{2}{*}{ K } & Jarak & \multicolumn{2}{c}{ Akurasi } \\
\cline { 3 - 4 } & & ciri minimum & ciri maksimum \\
\hline 3 & Cosine & $48,33 \%$ & $38,33 \%$ \\
& Euclidean & $48,33 \%$ & $56,67 \%$ \\
\multirow{3}{*}{5} & Cityblock & $76,67 \%$ & $51,67 \%$ \\
& Cosine & $35 \%$ & $25 \%$ \\
& Euclidean & $45 \%$ & $43,33 \%$ \\
\multirow{2}{*}{7} & Cityblock & $70 \%$ & $45 \%$ \\
& Cosine & $23,33 \%$ & $25 \%$ \\
& Euclidean & $40 \%$ & $43,33 \%$ \\
& Cityblock & $65 \%$ & $40 \%$ \\
\hline
\end{tabular}

Tabel 3 Akurasi pada Berbagai Jarak, Nilai K, dan Ciri yang Digunakan pada STFT

\begin{tabular}{cccc}
\hline \multirow{2}{*}{$\mathbf{K}$} & Jarak & \multicolumn{2}{c}{ Akurasi } \\
\cline { 3 - 4 } & & ciri minimum & ciri maksimum \\
\hline 3 & Cosine & $50 \%$ & $36,67 \%$ \\
& Euclidean & 51,675 & $56,67 \%$ \\
\multirow{2}{*}{5} & Cityblock & $70 \%$ & $41,67 \%$ \\
& Cosine & $25 \%$ & $25 \%$ \\
& Euclidean & $51,67 \%$ & $41,67 \%$ \\
\multirow{2}{*}{7} & Cityblock & $70 \%$ & $45 \%$ \\
& Cosine & $23,34 \%$ & $26,67 \%$ \\
& Euclidean & $46,67 \%$ & $43,34 \%$ \\
& Cityblock & $60 \%$ & $40 \%$ \\
\hline
\end{tabular}




\section{Simpulan}

Pada artikel ini dipaparkan penggunaan S-transform untuk ekstraksi ciri sinyal EKG pada klasifikasi sinyal EKG. S-transform memiliki kelebihan dalam hal resolusi yang relatif tinggi dibandingkan dengan spektrogram. Dari pengujian akurasi didapatkan akurasi tertinggi 76,67 persen menggunakan nilai minimum, jarak cityblock, dan $\mathrm{K}=3$. Hal ini menunjukkan bahwa $S$-transform menghasilkan akurasi yang lebih tinggi dibandingkan dengan STFT yang menghasilkan akurasi hingga 70 persen. Eksplorasi terhadap ciri yang lain dan berbagai parameter S-trasnform menarik untuk diteliti lebih lanjut. Penggunaan metoda yang diusulkan untuk analisis sinyal biomedis yang lain dapat dilakukan pada penelitian selanjutnya.

\section{Daftar Pustaka}

[1] T. A. M. Brosche, The EKG Handbook. Jones \& Bartlett Publisher, 2010.

[2] J. Rahul, M. Sora, and L. D. Sharma, "An overview on biomedical signal analysis," Int. J. Recent Technol. Eng., vol. 7, no. 5, pp. 206-209, 2019.

[3] A. Rizal and S. Hadiyoso, "ECG signal classification using Hjorth Descriptor," in Proceedings of the 2015 International Conference on Automation, Cognitive Science, Optics, Micro Electro-Mechanical System, and Information Technology, ICACOMIT 2015, 2016.

[4] I. Pázsit, "Analysis of heartbeat data with spectral and fractal techniques," Fluct. Noise Lett., vol. 5, no. 3, pp. L357-L363, 2005.

[5] A. Singh, D. Bhowmick, and S. Biswas, "Recognition of arrhythmic electrocardiogram using wavelet based feature extraction," in 2017 2nd International Conference for Convergence in Technology (I2CT), 2017, pp. 610-613.

[6] H. M. Rai, A. Trivedi, and S. Shukla, "ECG signal processing for abnormalities detection using multi-resolution wavelet transform and Artificial Neural Network classifier," Measurement, vol. 46, no. 9, pp. 3238-3246, 2013.

[7] Y. Xia, N. Wulan, K. Wang, and H. Zhang, "Detecting atrial fibrillation by deep convolutional neural networks," Comput. Biol. Med., vol. 93, no. July 2017, pp. 84-92, 2018.

[8] R. G. Stockwell, L. Mansinha, and R. P. Lowe, "Localization of the complex spectrum: the S transform," IEEE Trans. Signal Process., vol. 44, no. 4, pp. 998-1001, Apr. 1996.

[9] J. Huang, B. Chen, B. Yao, and W. He, "ECG Arrhythmia Classification Using STFTBased Spectrogram and Convolutional Neural Network," IEEE Access, 2019.

[10] B. S. Shaik, G. V. S. S. K. R. Naganjaneyulu, T. Chandrasheker, and A. V. Narasimhadhan, "A Method for QRS Delineation Based on STFT Using Adaptive Threshold," in Procedia Computer Science, 2015.

[11] W. J. Tompkins, "Electrocardiography," in Biomedical Digital Signal Processing, W. J. Tompkins, Ed. New Jersey: Prentice Hall, 2000, pp. 24-54.

[12] A. Rizal, "Perbandingan Skema Dekomposisi Paket Wavelet untuk Pengenalan Sinyal EKG," J. Nas. Tek. Elektro dan Teknol. Inf., vol. 4, no. 2, 2015.

[13] Physionet.org, "ECG Database." [Online]. Available: http://physionet.org/physiobank/database/\#ecg.

[14] A. Feltane, G. F. B. Bartels, J. Gaitanis, Y. Boudria, and W. Besio, "Human Seizure Detection Using Quadratic Renyi entropy," in 2013 6th International IEEE/EMBS Conference on Neural Engineering (NER), 2013, pp. 815-818.

[15] A. Rizal and V. Suryani, "Lung Sound Recognition Using Spectrogram and Adaptive Resonance Theory 2 Neural Network ( ART2 )," in Proceeding Biomedical Engineering Day 2008, 2008. 
[16] A. Rizal, R. Hidayat, and H. A. Nugroho, "Lung sounds classification using spectrogram's first order statistics features," in 2016 6th International Annual Engineering Seminar (InAES), 2016, pp. 96-100.

[17] F. Jin, F. Sattar, and D. Y. T. Goh, "Automatic wheeze detection using histograms of sample entropy.," in Annual International Conference of the IEEE Engineering in Medicine and Biology Society. IEEE Engineering in Medicine and Biology Society, 2008, vol. 2008, pp. 1890-3.

[18] Z. Esmaileyan and H. Marvi, "Recognition of emotion in speech using variogram based features," Malaysian J. Comput. Sci., vol. 27, no. 3, pp. 156-170, 2014. 